\title{
Boysenberry Flavor
}

National Cancer Institute

\section{Source}

National Cancer Institute. Boysenberry Flavor. NCI Thesaurus. Code C87298.

A characteristic of a medicinal product, specifying that its most predominant agreeable savor detected by the unified sensation of taste and olfactory receptors resembles boysenberry (Rubus ursinus $\mathrm{x}$ idaeus), a hybrid of a raspberry, a blackberry, and/or a loganberry. 